\title{
Hydroxyproline excretion in various forms of growth failure
}

\author{
W. M. TELLER, U. GENSCHER, H. BURKHARDT, and K. ROMMEL \\ Departments of Paediatrics, Endocrinology and Metabolism, and Section of Clinical Chemistry, Centre of Internal \\ Medicine and Paediatrics, University of Ulm, West Germany
}

Teller, W. M., Genscher, U., Burkhardt, H., and Rommel, K. (1973). Archives of Disease in Childhood, 48, 127. Hydroxyproline excretion in various forms of growth failure. The hydroxyproline excretion in 24-hour urines was determined in 26 children and adolescents whose heights were below the 3rd centile. In 14 growth failure was related to endocrine defects, and in 12 growth failure was unrelated to endocrine defect. The normal range of urinary hydroxyproline excretion at different ages was determined in 40 normal children aged between 3 and 14 years. All subjects were placed on a hydroxyproline-free diet before and during urine collections. Hydroxyproline excretion was expressed as $\mathrm{mg} / \mathrm{m}^{2}$ body surface per $24 \mathrm{hr}$.

Children with pituitary and hypothyroid dwarfism had decreased excretion of hydroxyproline. Giving growth hormone and/or thyroid hormone raised the hydroxyproline excretion to normal. Children with growth failure unrelated to endocrine defect had normal hydroxyproline excretion.

During childhood, urinary hydroxyproline excretion provides a useful means for distinguishing between endocrine dwarfism (low excretion) and non-endocrine dwarfism (normal excretion). In older adolescents and adults it is less reliable.

The amino acid hydroxyproline is formed by hydroxylation of proline within the collagen (for review see Adams, 1970), and 95\% of urinary hydroxyproline is derived from collagen in bones. Under conditions of a hydroxyproline-free diet the urinary excretion of hydroxyproline can be considered a parameter of bone metabolism and bone growth (for reviews see Kivirikko, 1970; Sjoerdsma et al., 1965).

Varying levels of hydroxyproline in 24-hour urines have been described in connexion with several skeletal disorders (Burkhardt, Dietrich, and Rommel, 1970; Filliat et al., 1965; Haddad, Couranz, and Avioli, 1970; Laitinen, Nikkila, and Kivirikko, 1966; Nakagawa et al., 1967; RuizTorres, 1969; Smiley and Ziff, 1964). Decreased hydroxyproline excretion has been described in hypopituitary and hypothyroid dwarfs (Chiumello and Del Guercio, 1965; Faglia, Norbiato, and Tirinnanzi, 1966; Graystone and Cheek, 1968; Haddad et al., 1970; Job et al., 1966; van Gemund, Vio, and Giesberts, 1968; Kivirikko and Laitinen, 1965; Kivirikko, Laitinen, and Lamberg, 1965;

Received 1 June 1972.
Mirouze et al., 1971; Nakagawa et al., 1967; Ruiz-Torres, 1969; Smiley and Ziff, 1964; Uitto et al., 1968). Patients with dwarfism due to long-term treatment with corticosteroids also had a decreased excretion of hydroxyproline (Matiasevic and Gershberg, 1966; Smith, Ansell, and Bywaters, 1968; Ward, Hartog, and Ansell, 1966). The administration of growth hormone to these patients as well as to hypopituitary dwarfs resulted in an increase in the excretion of hydroxyproline in the urine approaching normal levels (Chiumello and Del Guercio, 1965; Faglia et al., 1966; Graystone and Cheek, 1968; Haddad et al., 1970; Jasin et al., 1962; Job et al., 1966; Kopecky, 1971; Matiasevic and Gershberg, 1966; van Gemund et al., 1968; Smith et al., 1968; Ward et al., 1966). Similar results were obtained after treatment of hypothyroid dwarfs with thyroid hormones (Chiumello and Del Guercio, 1965; Faglia et al., 1966; Graystone and Cheek, 1968; van Gemund et al., 1968; Jasin et al., 1962; Job et al., 1966; Kivirikko et al., 1967a; Ruiz-Torres, 1969; Uitto et al., 1968).

In contrast to the many reports of urinary hydroxyproline excretion in dwarfism of endocrine aetiology, there are few in cases of the much 
commoner primordial dwarfism without demonstrable growth hormone deficiency. Such results as are reported are difficult to compare with one another because of different methods used for determination, and variations in food intake, while the hydroxyproline values so obtained have not been correlated with body weight or body surface or with the normal range of excretion at the age. In the present study the urinary hydroxyproline excretion of children with endocrine and primordial dwarfism was examined in order to reveal possible differences in the two groups. The values were compared to the hydroxyproline excretion of 40 normal children of various ages.

\section{Materials and methods}

Patients. The patients consisted of 26 children, 16 boys and 10 girls, aged from 3 to 19 years, with heights below the 3rd centile (Table I). Regarding their endocrine status, 5 children had only growth hormone deficiency, 3 combined lack of growth hormone and thyroid hormone, and 2 were deficient in growth hormone and gonadotrophins; one patient had dwarfism with high growth hormone levels: 3 had primary hypothyroidism. The remaining 12 children were considered to be 'primordial dwarfs' because of normal growth hormone levels: their presumptive diagnoses were 4 low birthweight dwarfism, 2 bird-headed dwarfism, 4 hereditary short stature, 2 uncertain diagnosis.

Each patient was subjected to a full endocrine survey (see below). Under standardized conditions their excretion of hydroxyproline was estimated in 24-hour urine. In 3 children with growth hormone deficiency and in the 1 girl with dwarfism and high growth hormone levels this estimation was repeated on the day of a single injection of $2.5 \mathrm{mg}$ human growth hormone (prepared according to the procedure of Roos, Fevold, and Gemzell, 1963).

Evaluation of patients with growth retardation. Height and weight. Comparison with standard curves by Vogt (1969) and centile curves as published by Vaughan (1969).

Bone age. Determination according to Greulich and Pyle (1959) by calculating the mean age of several bones.

Growth hormone $(G H)$. Determination of $\mathrm{GH}$ (Melani, Gröschel-Stewart, and Lawecki, 1968) before and during insulin-induced hypoglycaemia (decrease of blood sugar at least $40 \%$ of starting level).

Thyroid function. Determination of protein-bound iodine with autoanalyser technique according to Pollard, Garnett, and Webber (1965), $T_{3}$-in vitro-test according to Scholer (1962) (test pack of Byk-Mallinckrodt), and ${ }^{131}$ I-uptake.

Adrenal function. Determination of cortisol in plasma (Spencer-Peet, Daly, and Smith, 1965) before and 2 hours after injection of 25 IU of tetracosactrin (Synacthen) and during insulin-induced hypoglycaemia. Determination of 17-hydroxycorticosteroids in 24-hour urine (Few, 1961) before, during, and after suppression with metyrapone.

Gonadal function. In adolescent patients gonadotrophin levels were determined in 24-hour urines (test pack Luteonostikon-Organon), together with the excretion of testosterone (Pal, 1971) and of oestrogens (Ittrich, 1958).

Conditions of urine collections. 12 hours before starting the urine collection a hydroxyproline-free diet was given. During the following two days 24hour urines were collected separately for determination of hydroxyproline. The mean of both measurements was taken as the value of hydroxyproline excretion per day. The urine collections were obtained in the hospital under ward conditions. Incomplete collections were discarded.

Determination of hydroxyproline in urine. The hydroxyproline determination was performed according to the modification by Kivirikko et al. (1967b) of the method reported by Prockop and Udenfriend (1960), and expressed as $\mathrm{mg} / \mathrm{m}^{2}$ per 24 hours.

Normal values. The urinary excretion of hydroxyproline was estimated in 40 normal children (16 boys, 24 girls) aged 3 to 14 years. Urine collections were performed under the same conditions as described above. Mean values ( $\mathrm{mg}$ hydroxyproline $/ \mathrm{m}^{2}$ per 24 hours) \pm 2 SD were calculated at one-year intervals and provided our normal range of hydroxyproline excretion during childhood.

\section{Results}

Urinary hydroxyproline excretion of all but the 2 oldest of the 14 patients with endocrine disorders was below the normal range for their ages (Fig.). The values were lowest in the hypothyroid patients. Two 19-year-old hypopituitary dwarfs (Cases 9 and 10) had hydroxyproline excretion within the normal range. One injection of $2.5 \mathrm{mg}$ growth hormone in three children with hyposomatotropic dwarfism resulted in raised hydroxyproline excretion within the normal range. The 3-year-old girl with dwarfism and high growth hormone levels also revealed an increased hydroxyproline excretion after growth hormone injection, however it did not reach normal values.

All except 2 of the 12 children considered to be classifiable as 'primordial dwarfs' (Table II) had normal endocrine function, including $\mathrm{GH}$ response to insulin-induced hypoglycaemia. Two boys (Cases 17 and 24) showed subnormal GH values. One(Case 17), though clinically euthyroid, had a goitre 


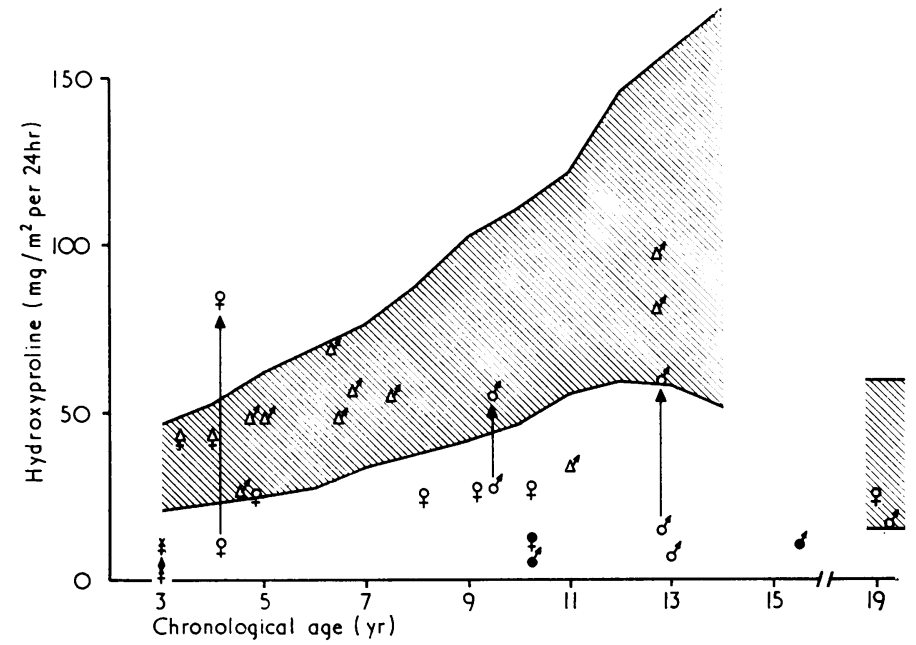

FIG.-Urinary excretion of hydroxyproline in dwarfism of different aetiology. Hatched area $=$ normal range $(M \pm 2 S D)$.

$\nearrow$ male; + female

$\bigcirc$ growth hormone deficiency

$O$ after

$\uparrow \quad$ a single dose of growth hormone

0 before
$X$ stunted growth with high levels of growth hormone $X$ after

$\uparrow \quad$ a single dose of growth hormone

$x$ before

- primary hypothyroidism

$\triangle$ non-endocrine (primordial) dwarfism

TABLE I

Clinical and laboratory data of patients with endocrine dwarfism of different aetiology (height below 3rd centile)

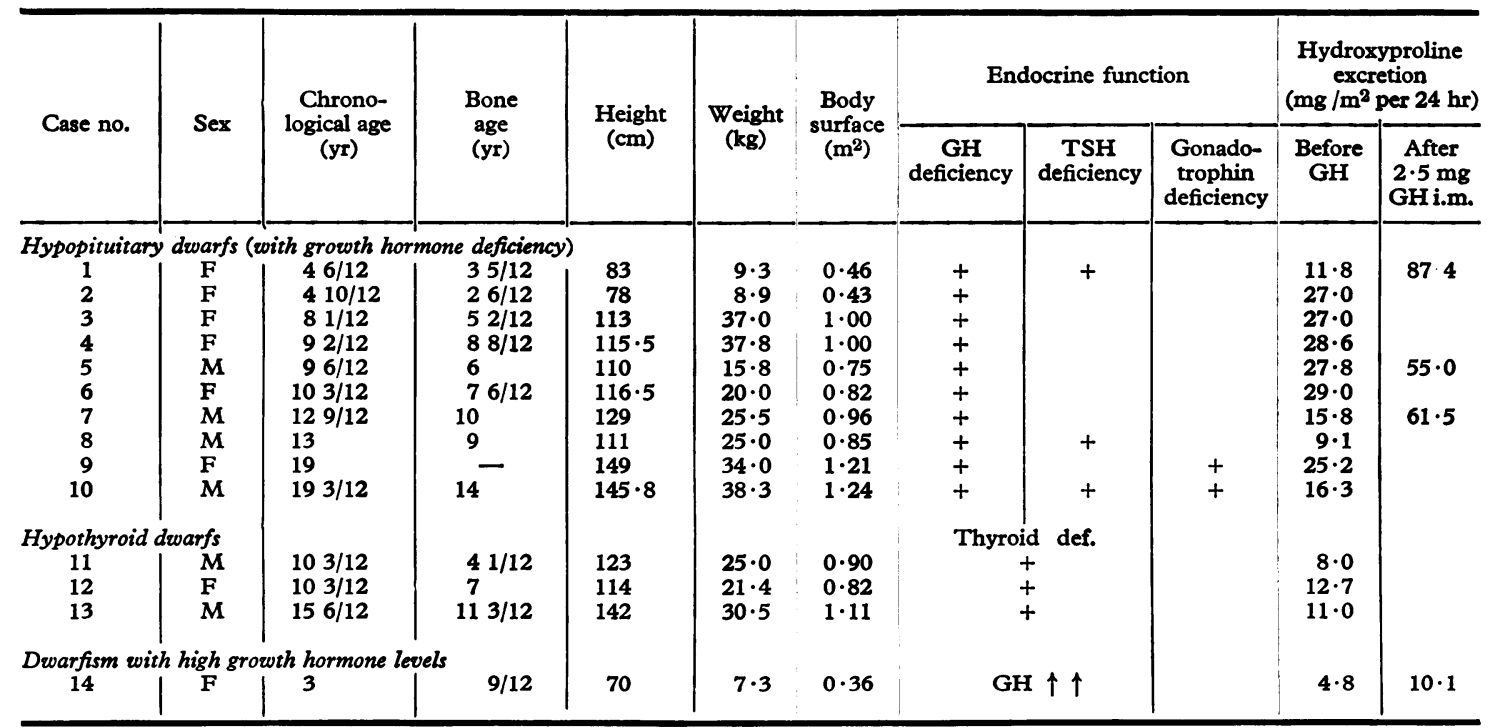

GH, growth hormone; TSH, thyroid stimulating hormone.

with high iodine avidity and a PBI of $4 \cdot 3 \mu \mathrm{g} / 100$ $\mathrm{ml}$; both had a subnormal excretion of hydroxyproline. The remaining 10 children in this group had a normal hydroxyproline excretion. 
TABLE II

Clinical and laboratory data of patients with nonendocrine (primordial) dwarfism (height below 3rd centile)

\begin{tabular}{|c|c|c|c|c|c|c|c|c|c|}
\hline $\begin{array}{l}\text { Case } \\
\text { no. }\end{array}$ & $\begin{array}{l}\text { Presumptive } \\
\text { classification }\end{array}$ & Sex & $\begin{array}{c}\text { Chronological } \\
\text { age } \\
\text { (yr) }\end{array}$ & $\begin{array}{l}\text { Bone } \\
\text { age } \\
\text { (yr) }\end{array}$ & $\begin{array}{l}\text { Height } \\
\text { (cm) }\end{array}$ & $\begin{array}{c}\text { Weight } \\
\text { (kg) }\end{array}$ & $\begin{array}{c}\text { Body } \\
\text { surface } \\
\left(\mathbf{m}^{2}\right)\end{array}$ & Endocrine function & $\begin{array}{l}\text { Hydroxyproline } \\
\text { excretion } \\
\left(\mathrm{mg} / \mathrm{m}^{2} \text { per } 24 \mathrm{hr}\right)\end{array}$ \\
\hline $\begin{array}{l}15 \\
16 \\
17\end{array}$ & $\begin{array}{c}\text { LBW } \\
\text { BHD } \\
?\end{array}$ & $\begin{array}{l}\text { F } \\
\text { F } \\
\text { M }\end{array}$ & $\begin{array}{l}36 / 12 \\
42 / 12 \\
47 / 12\end{array}$ & $\begin{array}{l}2 \\
21 / 12 \\
3\end{array}$ & $\begin{array}{l}89 \\
96 \\
96\end{array}$ & $\begin{array}{l}9 \cdot 8 \\
11 \\
12 \cdot 7\end{array}$ & $\begin{array}{l}0.49 \\
0.54 \\
0.58\end{array}$ & $\begin{array}{l}\text { Normal } \\
\text { Normal } \\
\text { Goitre (PBJ: } 4,3 \mu \mathrm{g} / \\
100 \mathrm{ml}) \text {; subnormal } \\
\text { GH response }\end{array}$ & $\begin{array}{l}43 \cdot 3 \\
43 \cdot 2 \\
27 \cdot 1\end{array}$ \\
\hline $\begin{array}{l}18 \\
19 \\
20 \\
21 \\
22 \\
23 \\
24 \\
25 \\
26\end{array}$ & $\begin{array}{l}\text { LBW } \\
\text { LBW } \\
\text { BHD } \\
\text { HSS } \\
\text { HSS } \\
\text { LBW } \\
? \\
\text { HSS } \\
\text { HSS }\end{array}$ & $\begin{array}{l}\mathbf{M} \\
\mathbf{M} \\
\mathbf{M} \\
\mathbf{M} \\
\mathbf{M} \\
\mathbf{M} \\
\mathbf{M} \\
\mathbf{M} \\
\mathbf{M}\end{array}$ & $\begin{array}{l}4 \quad 9 / 12 \\
5 \\
64 / 12 \\
66 / 12 \\
69 / 12 \\
76 / 12 \\
11 \\
128 / 12 \\
129 / 12\end{array}$ & $\begin{array}{l}210 / 12 \\
24 / 12 \\
3 \\
6 \\
36 / 12 \\
6 \\
11 \\
109 / 12 \\
12\end{array}$ & $\begin{array}{l}97 \cdot 8 \\
99 \cdot 3 \\
100 \\
108 \\
98 \cdot 1 \\
110 \\
127 \\
135 \cdot 2 \\
131 \cdot 5\end{array}$ & $\begin{array}{l}15 \cdot 3 \\
14 \cdot 7 \\
12 \cdot 8 \\
14 \cdot 2 \\
14 \cdot 7 \\
15 \cdot 8 \\
26 \cdot 7 \\
33 \cdot 5 \\
27 \cdot 4\end{array}$ & $\begin{array}{l}0 \cdot 64 \\
0.63 \\
0 \cdot 60 \\
0 \cdot 66 \\
0.63 \\
0 \cdot 70 \\
1 \\
1 \cdot 12 \\
1\end{array}$ & $\begin{array}{l}\text { Normal } \\
\text { Normal } \\
\text { Normal } \\
\text { Normal } \\
\text { Normal } \\
\text { Normal } \\
\text { Subnormal GH response } \\
\text { Normal } \\
\text { Normal }\end{array}$ & $\begin{array}{l}48 \cdot 4 \\
48 \cdot 8 \\
70 \cdot 2 \\
49 \cdot 2 \\
59 \\
55 \cdot 7 \\
33 \cdot 4 \\
82 \cdot 4 \\
98 \cdot 5\end{array}$ \\
\hline
\end{tabular}

GH, growth hormone; LBW, low birthweight dwarfism; HSS, hereditary short stature; BHD, bird-headed dwarfism; ?, uncertain diagnosis.

and Ziff, 1964; Whitehead, 1965; Zorab et al., 1970). Our present studies show that during childhood hydroxyproline excretion, when expressed per 24 hours per $\mathrm{m}^{2}$ body surface, can discriminate between stunted growth of endocrine origin and primordial dwarfism without endocrine disturbances, provided a hydroxyproline-free diet is ensured. Non-endocrine dwarfs have normal hydroxyproline excretion for their ages.

Several authors have reported on the wide scatter of hydroxyproline excretion in children when expressed in mg per 24 hours (Graf and Vest, 1971; Kivirikko and Laitinen, 1965; Zorab, 1969), and therefore sought correlations of hydroxyproline excretion with height, weight, body surface, age, and creatinine excretion (Allison, Walker, and Smith, 1966; Graf and Vest, 1971; Graystone and Cheek, 1968; Job et al., 1966; Jones et al., 1964; Kivirikko, 1970; Nakagawa et al., 1967; Wharton et al., 1972; Whitehead, 1965). Kivirikko (1970) emphasized the need for a hydroxyproline-free diet if large variations of hydroxyproline excretion due to alimentary factors were to be eliminated. Kivirikko and Laitinen (1965) and Job et al. (1966) had previously found no differences in hydroxyproline excretions in endocrine and non-endocrine dwarfs, but the number of patients was small, and in some the endocrine status may have been incompletely evaluated, while the age dependent normal ranges and the need for a hydroxyproline-free diet had been disregarded.

Van Gemund et al. (1968) reported a relation between hydroxyproline excretion of normal children and patients with endocrine and non-endocrine growth failure similar to our own findings, though they did not give a hydroxyproline-free diet, nor express their values in terms of $\mathrm{mg}$ hydroxyproline/ $24 \mathrm{hr}$ per $\mathrm{m}^{2}$.

Children who are stunted for no apparent reason (primordial dwarfs) seem to have normal cell metabolism including collagen turnover. Therefore it is not surprising to find that they excrete normal amounts of hydroxyproline per cell mass unit (e.g. $\mathrm{m}^{2}$ body surface). Different mechanisms have to be assumed to account for the decreased hydroxyproline excretion when the growth failure is due to lack of growth and/or thyroid hormones. Growth hormone increases protein synthesis. Daughaday and Mariz (1962) studied the hydroxylation of ${ }^{14} \mathrm{C}$-labelled proline in cartilage of rats and found it to be diminished in hypophysectomized animals. After the administration of growth hormone this decrease disappeared. Additional effects of growth hormone on collagen transformation and catabolism were ruled out by Aer et al. (1968).

In vitro studies by Daughaday and Mariz (1962) and Henneman (1971) showed that in bone other factors besides growth hormone must have an influence on the hydroxylation of proline to hydroxyproline. A lack of these factors, e.g. sulphation factor, has been suggested as a possible cause of those cases of dwarfism having raised growth hormone levels. Such a mechanism might explain the only slight increase in hydroxyproline excretion in our patient (Case 12, Table I) after the injection of growth hormone.

Kivirikko et al. (1963, 1967a, b) and Kivirikko, Koivusalo, and Laitinen (1964) consider that the low hydroxyproline excretion in hypothyroid 


\section{Hydroxyproline excretion in various forms of growth failure}

individuals may be due to decreased synthesis of collagen in addition to diminished catabolism. Kivirikko et al. (1965) and Mirouze et al. (1971) found a good correlation between PBI levels and urinary hydroxyproline excretion. Job et al. (1966) noted a correlation between growth velocity and hydroxyproline excretion in normal children. The increased hydroxyprolinuria after dwarfs have been treated with growth hormone has been used as a measure of growth hormone sensitivity (van Gemund et al., 1968).

We conclude that in childhood hydroxyproline excretion, provided a hydroxyproline-free diet is given and results are expressed as $\mathrm{mg} / \mathrm{m}^{2}$ per 24 $\mathrm{hr}$, may provide an easy and helpful adjunct in distinguishing between endocrine and non-endocrine (primordial) dwarfism, since only the latter gives normal values. In older adolescents and adults the test is less reliable.

We thank Dr. Pal for steroid determinations and Dr. Schröder for growth hormone determinations in the patients studied.

\section{REFERENCES}

Adams, E. (1970). Metabolism of proline and of hydroxyproline. In International Review of Connective Tissue Research, Vol. 5, p. 2. Ed. by D. A. Hall, and D. S. Jackson. Academic Press, New York and London.

Aer, J., Halme, J., Kivirikko, K. I., and Laitinen, O. (1968). Action of growth hormone on the metabolism of collagen in the rat. Biochemical Pharmacology, 17, 1173.

Allison, D. J., Walker, A., and Smith, Q. T. (1966). Urinary hydroxyproline: creatinine ratio of normal humans at various ages. Clinica Chimica Acta, 14, 729.

Burkhardt, H., Dietrich, M., and Rommel, K. (1970). Diagnostik der Knochenbeteiligung beim Morbus Hodgkin. Deutsche medizinische Wochenschrift, 95, 1009.

Chiumello, G., and Del Guercio, M. J. (1965). Modificazioni della idrossiprolinuria nel trattamento dell'ipotiroidismo e del nanismo ipopiruitarico. Minerva Pediatrica, 17, 1069.

Daughaday, W. H., and Mariz, I. K. (1962). Conversion of proline-U-C $\mathrm{C}^{14}$ to labelled hydroxyproline by rat cartilage in vitro: Effects of hypophysectomy, growth hormone, and cortisol. Fournal of Laboratory and Clinical Medicine, 59, 741.

Faglia, G., Norbiato, G., and Tirinnanzi, M. L. (1966). L'idrossiprolina totale urinaria in stati de nanismo di varia origine. Atti della Accademia Medica Lombarda, 21, 501.

Few, J. D. (1961). A method for the analysis of urinary 17-hydroxycorticosteroids. Fournal of Endocrinology, 22, 31.

Filliat, M., Brunet, M., Cotte, J., Romagny, G., Rebouillat, J., Site, J., and Gilly, R. (1965). Hydroxyproline urinaire chez l'enfant. Valeurs normales et pathologiques. Etude preliminaire portant sur 200 dosages. Pédiatrie, 20, 925.

van Gemund, J. J., Vio, P. M. A., and Giesberts, M. A. H. (1968). De klinische betekenis van de hydroxyproline-uitscheiding in de urine bij kinderen. Maandschrift voor Kindergeneeskunde, $35,387$.

Graf, U., und Vest, M. (1971). Zur normalen Hydroxyprolinausscheidung im Urin bei Săuglingen, Kindern und Adoleszenten. Zeitschrift für Kinderheilkunde, 110, 128.

Graystone, J. E., and Cheek, D. B. (1968). Hydroxyproline excretion. In Human Growth, p. 221. Ed. by D. B. Cheek. Lea and Febiger, Philadelphia.

Greulich, W. W., and Pyle, S. I. (1959). Radiographic Atlas of Skeletal Development of the Hand and Wrist, 2nd ed. Stanford University Press, Stanford, California; Oxford University Press, London.
Haddad, J. G., Jr., Couranz, S., and Avioli, L. V. (1970). Nondialyzable urinary hydroxyproline as an index of bone collagen formation. Fournal of Clinical Endocrinology, 30, 282.

Henneman, D. H. (1971). Growth hormone inhibition of proline hydroxylation in vitro. American fournal of Physiology, 220, 1808.

Ittrich, G. (1958). Eine neue Methode zur chemischen Bestimmung der östrogenen Hormone im Harn. Hoppe-Seyler's Zeitschrift für physiologische Chemie, 312, 1.

Jasin, H. E., Fink, C. W., Wise, W., and Ziff, M. (1962). Relationship between urinary hydroxyproline and growth. Fournal of Clinical Investigation, 41, 1928.

Job, J. C., Sizonenko, P., Pakey, J. P., Pakey, P., Bourdon, R., and Rossier, A. (1966). L'hydroxyproline urinaire chez l'enfant normal et dan les retards de croissance. Archives Françaises de Pédiatrie, 23, 679.

Jones, C. R., Bergman, M. W., Kittner, P. J., and Pigman, W. W. (1964). Urinary hydroxyproline excretion in normal children and adolescents. Proceedings of the Society for Experimental Biology and Medicine, 115, 85.

Kivirikko, K. I (1970). Urinary excretion of hydroxyproline in health and disease. In International Review of Connective Tissue Research, Vol. 5, p. 93. Ed. by D. A. Hall and D. S. Jackson. Academic Press, New York and London.

Kivirikko, K. I., Koivusalo, M., and Laitinen, O. (1964). Further studies on the action of thyroid hormones on the metabolism of collagen. Acta Physiologica Scandinavica, 61, 49.

Kivirikko, K. I., Koivusalo, M., Lattinen, O., and Liesmaa, M. (1963). Effect of thyroxine on the hydroxyproline in rat urine and skin. Acta Physiologica Scandinavica, 57, 462.

Kivirikko, K. I., and Laitinen, O. (1965). Clinical significance of urinary hydroxyproline determinations in children. Annales Paediatriae Fenniae, 11, 148.

Kivirikko, K. I., Laitinen, O., Aer, J., and Halme, J. (1967a), Metabolism of collagen in experimental hyperthyroidism and hypothyroidism in the rat. Endocrinology, 80, 1051.

Kivirikko, K. I., Laitinen, O., and Lamberg, B. A. (1965). Value of urine and serum hydroxyproline in the diagnosis of thyroid disease. Fournal of Clinical Endocrinology, 25, 1347.

Kivirikko, K. I., Laitinen, O., and Prockop, D. J. (1967b). Modifications of a specific assay for hydroxyproline in urine. Analytical Biochemistry, 19, 249.

Kopecky, A. (1971). Hydroxyprolinuria in pituitary dwarfs given human somatotropin. In 2nd International Symposium on Growth Hormone. Internat. Congr. Series No. 236, p. 60/61. Ed. by A. Pecile and E. E. Muller. Excerpta Medica, Amsterdam.

Laitinen, O. Nikkila, E. A., and Kivirikko, K. I. (1966). Hydroxyproline in the serum and urine. Normal values and clinical significance. Acta Medica Scandinavica, 179, 275.

Matiasevic, D., and Gershberg, H. (1966). Studies on hydroxyproline excretion and corticosteroid-induced dwarfism: Treatment with human growth hormone. Metabolism, 15, 720.

Melani, F., Gröschel-Stewart, U., and Lawecki, J. (1968). Radioimmunoassay of human growth hormone using the double antibody technique. Acta Endocrinologica (København), 57, 549.

Mirouze, J., Jaffiol, C., Simon, C., and Monnier, L. (1971). L'hydroxyprolinurie dans les maladies thyroidiennes. Annales d'Endocrinologie, 32, 132.

Nakagawa, M., Sugiura, Y., Oshima, T., Kajing, G., Hirakoh, H., and Yamada, Y. (1967). Urinary hydroxyproline excretion in orthopedic disease, with special reference to systemic bone disease and bone tumor. Nagoya Fournal of Medical Science, $29,345$.

Pal, S. B. (1971). Urinary excretion of testosterone and epitestosterone in men, women and children, in health and disease. Clinica Chimica Acta, 33, 215.

Pollard, A. C., Garnett, E. S., and Webber, C. (1965). An automated technic for the assessment of thyroid status, based upon the binding of $\mathrm{I}^{131}$-triiodothyronine by serum. Clinical Chemistry, 11, 959.

Prockop, D. J., and Udenfriend, S. (1960). A specific method for the analysis of hydroxyproline in tissues and urine. Analytical Biochemistry, 1, 228.

Roos, P., Fevold, H. R., and Gemzell, C. A. (1963). Preparation of human growth hormone by gel filtration. Biochimica et Biophysica Acta, 74, 525. 
Ruiz-Torres, A. (1969), Klinische Bedeutung der Bestimmung der Hydroxyprolinurie. Medizinische Welt (Stuttgart), 40, 2176.

Scholer, J. F. (1962). A simple measure of thyrobinding by plasma: a test of thyroid-function. Fournal of Nuclear Medicine, 3, 41.

Sjoerdsma, A., Udenfriend, S., Keiser, H., and LeRoy, E. C. (1965). Hydroxyproline and collagen metabolism. 'Clinical implications. Annals of Internal Medicine, 63, 672.

Smiley, J. D., and Ziff, M. (1964). Urinary hydroxyproline excretion and growth. Physiological Reviews, 44, 30.

Smith, M., Ansell, B. M., and Bywaters, E. G. L. (1968). Urinary hydroxyproline excretion in patients with juvenile rheumatoid arthritis, with and without corticosteroid therapy. Fournal of Pediatrics, 73, 875.

Spencer-Peet, J., Daly, J. R., and Smith, V. (1965). A simple method for improving the specificity of the fluorimetric determination of adrenal cortucosteroids in human plasma. Fournal of Endocrinology, 31, 235.

Uitto, J., Laitinen, O., Lamberg, B. A., and Kivirikko, K. I. (1968). Further evaluation of the significance of urinary hydroxyproline determinations in the diagnosis of thyroid disorders. Clinica Chemica Acta, 22, 583.

Vaughan, V. C., III (1969). Growth and development. In Textbook of Pediatrics, 9th ed., p. 15. Ed. by W. E. Nelson,
V. C. Vaughan, III, and R. J. McKay. Saunders, Philadelphia, London and Toronto.

Vogt, D. (1969). Wachstum und Entwicklung des gesunden Kindes. In Lehrbuch der Kinderheilkunde, 3rd ed., p. 1. Ed. by W. Keller and A. Wiskott. Thieme, Stuttgart.

Ward, D. J., Hartog, M., and Ansell, B. M. (1966). Corticosteroidinduced dwarfism in still's disease treated with human growth hormone. Clinical and metabolic effects including hydroxyproline excretion in two cases. Annals of the Rheumatic Diseases, 25, 416.

Wharton, B. A., Gough, G., Williams, A., Kitts, S., and Pennock, C. A. (1972). Urinary total hydroxyproline : creatinine ratio. Archives of Disease in Childhood, 47, 74.

Whitehead, R. G. (1965). Hydroxyproline creatinine ratio as an index of nutritional status and rate of growth. Lancet, 2, 567.

Zorab, P. A. (1969). Normal creatinine and hydroxyproline excretion in young persons. Lancet, $2,1164$.

Zorab, P. A., Clark, S., Harrison, A., and Seel, J. R. (1970). Hydroxyproline excretion and height velocity in adolescent boys. Archives of Disease in Childhood, 45, 763.

Correspondence to Professor Walter Teller, Universitäts-Kinderklinik, Prittwitzstrasse 43, D $79 \mathrm{Ulm} /$ Donau, West Germany. 